\title{
Interaksi Simbolik dalam Word of Mouth Untuk Mengenalkan Iphone di Kalangan Persahabatan (Studi Etnografi Teori Peran \\ Pengambilan Keputusan dalam Lingkungan Persahabatan)
}

\author{
Daniel Christofer, Muhammad Adi Pribadi \\ danielchristo25@gmail.com,adip@fikom.untar.ac.id
}

Fakultas Ilmu Komunikasi Universitas Tarumanagara

\begin{abstract}
The purpose of introducing the Iphone to friends in an environment of friendship is to influence an environment so that there is a common use of the product. The Iphone itself is one of the best mobile phones in its class compared to other competitors. Iphone users who are satisfied will be a promotional medium with word of mouth theory and will try to influence the environment so that they are like themselves. Consumers who have positive feedback according to role theory will act as initiators and influencers who will try to incorporate thoughts as Iphone users into their environment. The initiator himself tries to do one of the symbolic interaction theories, namely the pygmalion effect where a thinker turns into a reality. This research was conducted with the aim to find out how much the role of social interaction that occurs in an environment can influence the purchase decision of a product or service. This research is different from previous studies because on this occasion symbolic interactions were examined through word of mouth.
\end{abstract}

Keywords: iphone, pygmalion effect, symbolic interaction, word of mouth

\begin{abstract}
Abstrak
Tujuan mengenalkan Iphone kepada para sahabat dalam lingkungan persahabatan adalah untuk memengaruhi sebuah lingkungan agar terjadi kesamaan penggunaan produk. Iphone sendiri merupakan salah satu handphone terbaik di kelasnya dibanding kompetitor lainnya. Para pengguna Iphone yang merasa puas akan menjadi media promosi dengan teori word of mouth, dan akan mencoba untuk memengaruhi lingkunga nya agar seperti dirinya. Konsumen yang memiliki feedback positif menurut teori peran akan bertindak sebagai initiator dan juga influencer yang akan mencoba memasukkan pemikiran sebagai pengguna Iphone ke dalam lingkungannya. Initiator sendiri mencoba melakukan salah satu teori interaksi simbolik yaitu pygmalion effect dimana sebuah pemikirin berubah menjadi sebuah kenyataan. Penelitian ini dilakukan dengan tujuan mengetahui peran interaksi sosial yang terjadi di sebuah lingkungan dalam memengaruhi keputusan pembelian sebuah produk maupun jasa. Penelitian kali ini berbeda dari penelitian terdahulu karena pada kesempatan kali ini interaksi simbolik yang dikaji melalui word of mouth.
\end{abstract}

Kata Kunci: interaksi simbolik, iphone, pygmalion effect, word of mouth

\section{Pendahuluan}

Brand loyalty merupakan sebuah kesetiaan pelanggan kepada sebuah produk ataupun jasa. Kesetiaan sendiri berarti rasa ingin selalu menggunakan sebuah produk maupun jasa sebuah brand yang sudah dipercaya tanpa terbesitnya pemikiran untuk mencoba produk lain. Kepercayaan terhadap kualitas yang diberikan, fasilitas, dan 
juga kenyamanan yang diberikan oleh brand tersebut merupakan beberapa faktor yang dapat memicu timbulnya rasa kepuasan pelanggan sehingga dapat terciptanya ikatan antara seorang konsumen terhadap sebuah brand, sehingga terbentuknya brand loyalty.

Pihak produsen pun menginginkan agar konsumen yang sudah terjaring dan juga merupakan pengguna produk dan jasanya dapat dipertahankan dan juga dijaga baik relasi. Pada kenyatannya hal tersebut tidak mudah dicapai karena terdapat faktor eksternal maupun internal yang menjadi penghalang. Terdapat cara yang bisa dilakukan untuk mewujudkan hal tersebut yaitu menjaga mutu dan kinerja brand agar kepuasaan pelanggan dapat terpenuhi dengan sendirinya, sebuah brand harus dapat melampaui ekspektasi para konsumen nya agar dapat menarik hati dan juga minat para pelanggan.

Konsumen yang terpuaskan oleh kinerja perusahaan akan menjadi media promosi yang dapat merambah bagian-bagian yang sulit dijangkau oleh perusahaan, salah satu media promosi ini dapat disebut sebagai word of mouth. Calon konsumen akan lebih mungkin untuk membeli sebuah produk ataupun jasa jika mendapatkan referensi dan juga informasi dari pihak yang sudah dikenalnya. Konsumen yang memiliki feedback positif tersebut akan secara sukarela untuk mempromosikan sebuah brand, sehingga terjadinya direct promotion langsung kepada calon konsumen. Keuntungan seperti ini berdampak sangat baik bagi sebuah brand karena akan adanya promosi efektif yang didapatkan secara cuma-cuma namun memiliki dampak yang signifikan.

Teori interaksi simbolik yang dikemukakan oleh George Herbert Mead dan Herbert Blumer menganut pemikiran manusia yaitu terjadinya proses sosial pada kehidupan sehari-hari yang terkait dengan makna subjektif. Menurut George interaksi simbolik terbagi menjadi tiga bagian yang merupakan pikiran, diri, dan masyarakat. Ketiga poin tersebut saling berkait dan juga terhubung.

Menurut Percy dan Elliot (2012) adanya peran pada pengambilan keputusan pembelian. Menurut penelitian peran dapat dibagi menjadi lima yaitu initiator, influencer, decider, purchaser, dan juga user. Kelima peran tersebut memiliki bagian masing-masing pada proses pengambilan keputusan pembelian.

\section{Metode Penelitian}

Metode penelitian yang digunakan oleh peneliti adalah kualitatif. Pada penelitian kualitatif penelitian akan difokuskan kepada studi pada fenomena sosial, pemberian suara pada perasaan, dan juga persepsi para partisipan. Penelitian kali ini bertujuan untuk mengetahui interaksi simbolik yang terjadi di dalam lingkungan persahabatan dapat menimbulkan brand loyalty dan juga terdapat nya peran-peran yang terbentuk untuk proses keputusan pembelian.

Studi kasus merupakan salah satu metode untuk meneliti sebuah kasus, pada teori yang ada studi kasus terbagi menjadi tiga yaitu eksplantoris, deskriptif, dan juga studi kasus eksplantoris. Terdapat beberapa hal yang dapat mempengaruhi hasil penelitian yaitu data-data yang didapatkan dan juga telah terkumpul terlalu sedikit dan kurang informatif untuk generalisasi ilmiah, terlalu banyak nya data yang didapatkan juga merupakan hal yang baik karena data yang berlebihan akan membuat informasi nya tertumpuk sehingga berdampak kepada fokus penelitian.

Studi kasus sendiri merupakan sebuah inkuiri empiris yang bermanfaat untuk mempelajari fenomena yang ada pada kehidupan sehari-hari. Pada pelaksanaan nya 
Daniel Christofer, Muhammad Adi Pribadi: Interaksi Simbolik dalam Word of Mouth Untuk Mengenalkan Iphone di Kalangan Persahabatan (Studi Etnografi Teori Peran Pengambilan Keputusan dalam Lingkungan Persahabatan)

diperlukan rencana dan juga sumber-sumber yang baik sehingga kesalahan-kesalahan dan faktor yang dapat menyebabkan kegagalan penelitian dapat dihindari. Terdapat empat bagian pada metode penelitian yang digunakan yaitu dengan mengajukan pertanyaan yang sesuai dengan rujukan penelitian, relevansi data, pengumpulan data, dan juga analisis data. Setelah data-data yang sesuai didapat dari hasil penelitian, data harus dapat dianalisis dengan sebaik mungkin agar dapat mendapatkan hasil sesuai yang diinginkan.

Melalui proses observasi lah seorang peneliti dapat memahami dan juga mengerti secara lebih baik permasalahan yang diteliti. Peneliti memanfaatkan observasi partisipan karena peneliti sendiri berada di dalam lingkungan subjek penelitian. Dengan cara seperti ini seorang peneliti dapat mengerti dan mengumpulkan informasi secara lebih rinci dan juga sistematis. Peluang untuk peneliti mendapatkan akses kepada data-data dan juga aktivitas subjek penelitian akan lebih besar dan juga detil.

Dengan wawancara mendalam peneliti akan mencoba untuk mendapatkan informasi sesuai dengan yang dibutuhkan untuk penelitian. Wawancara yang dilakukan oleh peneliti merupakan wawancara open ended sehingga para responden nantinya dapat menjabarkan dan juga mengutarakan seluruh pendapatnya secara terbuka tanpa batas sehingga nanti data yang didapat akan lebih variatif dan juga natural sebagaimana yang diharapkan oleh peneliti sendiri.

Interaksi yang terbentuk pada individu dapat berkembang dengan adanya simbol-simbol yang tercipta pada lingkungan itu sendiri. Realitas sosial merupakan rangkaian peristiwa yang seringkali terjadi pada individu di kehidupan sosial, interaksi yang dilakukan terjadi secara sadar dan memiliki kaitan terhadap seluruh komponnen yang dapat menyampaikan pengoperan simbol-simbol komunikasi. Dengan mencoba masuk ke dalam dunia konseptual manusia, diharapkan dapat mengerti dan juga paham akan bagaimana sebuah realitas sosial dapat terbentuk dari pemahaman individu itu sendiri. Realitas yang ini dipercayai merupakan realita yang benar adanya terjadi, bukan merupakan sebuah realitas palsu yang terbentuk antara seorang individu kepada lingkungannya.

\section{Hasil Temuan Dan Diskusi}

Iphone adalah produk telepon seluler yang dikeluarkan oleh perusahaan apple, Iphone pertama kali diperkenalkan ke publik pada tanggal 9 januari 2007 dan diluncurkan secara langsung oleh Steve Jobs. Iphone pertama yang dijual ke konsumen hanya menggunakan resolusi layar sebesar 3,5 inci, dan juga dengan sistem penyimpanan sebesar $4 \mathrm{gb}$ dan juga $8 \mathrm{gb}$. Pada generasi pertama telepon seluler ini memiliki sangat banyak kekurangan dan fitur-fitur yang tidak disematkan seperti tidak dapatnya melakukan multitasking, tidak ada nya toko belanja aplikasi atau yang kita kenal dengan "app store".

Pada tahun 2008 Iphone generasi kedua lahir dan juga diperkenalkan ke khalayak luas. Dengan proses perkembangan dan penelitian yang semakin baik dimiliki oleh apple Iphone dapat bertransformasi dengan lebih baik seiring dengan berjalan nya waktu. Banyak produsen-produsen telepon seluler lainnya ingin mencoba membuat fitur serupa seperti yang dimiliki Iphone namun hingga saat ini belum ada yang dapat menyamai fitur tersebut sehingga dapat dikatakan Iphone masi menjadi salah satu pilihan terbaik di kelasnya. 
Gambar 1. Steve Jobs Mengenalkan Iphone

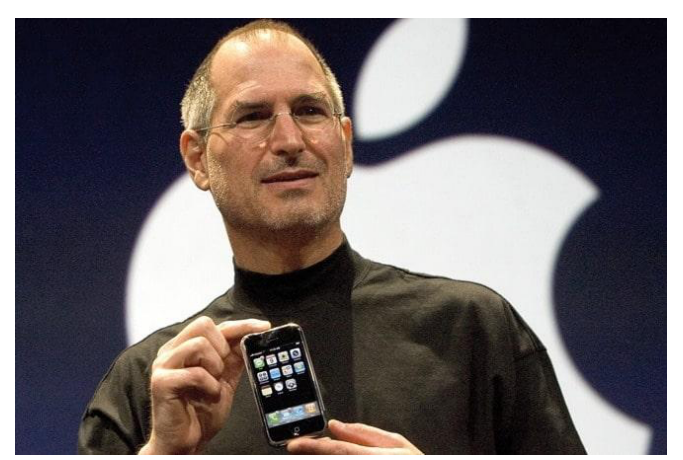

Sumber: Internet

Pada awalnya nama Iphone sendiri bukan merupakan nama yang dimiliki oleh apple melainkan dimiliki oleh perusahaan cisco. Nama Iphone pertama kali digunakan oleh perusahaan bernama infogear untuk menamai perangkat telepon rumah. Pada saat peluncuran Iphone pertama kali Steve Jobs menyadari bahwa nama "Iphone" sendiri dimiliki oleh perusahaan cisco, namun dengan negosiasi yang panjang akhirnya apple dapat mengakuisisi merek dagang tersebut dengan perjanjian kedua belah pihak dapat menggunakan nama tersebut secara sah di mata hukum.

Keberhasilan apple dalam pemilihan logo perusahaan menimbulkan berbagai mitos-mitos terkait logo tersebut, sehingga banyak rumor dan kabar yang beredar diantara masyarakat. Di dalam perkembangan nya logo apple sudah berganti sebanyak 6 kali dimulai dari pertama kali perusahaan ini didirikan yaitu pada tahun 1976. Pada akhirnya desainer logo apple membuka suara dan mengatakan, kala itu Steve jobs hanya meminta beliau untuk menggambarkan dan juga mendesain logo dengan outline apel Dalam hal pemilihan logo ini Steve Jobs merupakan orang yang sangat menghargai filosofi dan arti di dalam sebuah logo guna menunjang kesuksesan dan akar daripada sebuah perusahaan.

Di dalam penelitian kali ini peneliti memanfaatkan beberapa teori yaitu teori interaksi simbolik, studi etnografi, teori peran dan juga $e$-wom. Peneliti melakukan wawancara dengan pihak-pihak terkait yang memiliki data dan juga informasi yang dibutuhkan oleh peneliti. Penelitian ini memiliki arah untuk meneliti bagaimana sebuah produk telepon genggam dari apple yang bernama Iphone dapat memiliki sebuah pengaruh dan juga makna didalam lingkungan persahabatan.

Initiator merupakan salah satu peran dalam proses pengambilan keputusan pembelian yang memiliki peran sebagai pihak yang menyarankan dan juga memulai sebuah proses keputusan pembelian. Pada dasarnya seorang initiator ingin memasukkan ideologi dan juga keinginan nya kepada lingkungan nya untuk mengikuti jejak yang sudah ia tempuh. Di dalam penelitian kali ini peneliti memanfaatkan beberapa teori yaitu teori interaksi simbolik, studi etnografi, teori peran dan juga $e$ wom. Peneliti melakukan wawancara dengan pihak-pihak terkait yang memiliki data dan juga informasi yang dibutuhkan oleh peneliti. Penelitian ini memiliki arah untuk meneliti bagaimana sebuah produk telepon genggam dari apple yang bernama Iphone dapat memiliki sebuah pengaruh dan juga makna didalam lingkungan persahabatan. Kondisi seperti ini saling berkait dengan teori interaksi simbolik dalam sygnificant symbol (mind/pikiran), dimana konsumen merasakan sebuah kepuasan atas kinerja dan hasil yang diberikan oleh Iphone dalam setiap perangkat telepon seluler yang dirilis 
Daniel Christofer, Muhammad Adi Pribadi: Interaksi Simbolik dalam Word of Mouth Untuk Mengenalkan Iphone di Kalangan Persahabatan (Studi Etnografi Teori Peran Pengambilan Keputusan dalam Lingkungan Persahabatan)

sehingga akan menjadikan kepuasan konsumen ini untuk menjadi setia terhadap Iphone.

Influencer merupakan peran kedua yang memiliki peran sebagai pihak yang memberikan rekomendasi ataupun membatalkan sebuah proses keputusan pembelian. Seorang influencer merupakan pihak yang sudah memiliki pengalaman yang cukup baik sehingga dapat menilai sebuah produk ataupun jasa layak untuk dibeli ataupun tidak. Influencer sendiri dapat menjadi pihak penentu apakah sebuah proses terjadinya keputusan pembelian itu dapat berjalan semakin baik maupun sebaliknya.

Decider merupakan peran yang mengambil keputusan apakah akan melakukan proses pembelian atau tidak. Seseorang yang memegang peran decider merupakan pihak yang akan memutuskan apakah produk dan jasa yang seorang initiator dan influencer sarankan patut untuk dibeli dan digunakan. Untuk sebagian besar keputusan pembelian skala kecil biasanya hanya akan terdapat satu decider namun jika keputusan pembelian skala menengah menuju besar akan terdapat decider lebih dari orang.

Purchaser merupakan peran yang berada pada tahap pembelian sebuah produk atau jasa. Peran ini timbul setelah adanya decider yang memutuskan bahwa produk atau jasa yang di rekomendasikan oleh para initiator dan juga influencer pantas untuk dibeli. Seorang purchaser akan memiliki ekspektasi yang tinggi sebagaimana yang diiming-imingi oleh pihak yang merekomendasikan, sehingga terjadilah proses pembelian. Purchaser sendiri juga bisa merupakan seorang user yang melakukan pembelian kembali karena merasa puas dan juga senang akan produk atau jasa tersebut.

User merupakan peran paling akhir daripada peran yang lainnya, user sendiri merupakan peran yang memiliki arti sebagai pengguna atau penikmat daripada produk atau jasa yang direkomendasikan. User yang mendapati ekspektasinya terwujud sehingga mendapatkan kepuasan akan mengulangi proses yang sama untuk mempengaruhi lingkungan berikutnya. Sementara user yang memiliki pengalaman yang kurang baik akan bertindak sebagai influencer untuk mencegah terjadinya pembelian oleh pihak lain di kemudian hari.

\section{Simpulan}

Berdasarkan hasil penelitian dan juga analis data yang dimiliki oleh peneliti, maka ditemukan kesimpulan yang menarik sebagai berikut :

a. Interaksi simbolik yang terjadi di dalam sampel penelitian memiliki peran yang sangat penting dalam terbentuknya keputusan pembelian untuk menggunakan Iphone, yang hadir dari word of mouth di dalam lingkungan persahabatan sehingga calon pengguna akan lebih percaya untuk menggunakan produk tersebut untuk mengharapkan terjadinya pygmalion effect(mind/pikiran) agar dapat memengaruhi sahabat lainnya untuk menggunakan Iphone.

b. Komunikasi yang terjadi diantara sahabat banyak memiliki arti khusus yang hanya dapat dimengerti oleh kelompok itu sendiri, sehingga teori bahasa dari studi etnografi dapat di jalankan di dalam kehidupan sehari-hari

c. Dengan terjadinya kepuasan konsumen dalam penggunaan produk akan secara otomatis terbentuk brand loyalty, hal tersebut dapat terjadi karena produk yang mereka gunakan sudah menyamai bahkan melampaui ekspektasi yang mereka inginkan pada saat membelinya. 


\section{Ucapan Terima Kasih}

Penelitian ini dapat terwujud dan dilancarkan dalam segala prosesnya karena bantuan dari Tuhan YME, serta dukungan dari para pihak-pihak yang turut berpartisipasi dan juga memberikan dukungan kepada peneliti. Maka dari itu peneliti ingin mengucapkan terima kasih yang sebesar-besarnya kepada sahabat-sahabat peneliti yang telah berada di sisi peneliti untuk memberikan berbagai dukungan.

\section{Daftar Pustaka}

Percy, Larry., Elliot, Richard Rosenbaum. 2012. Strategic Advertising Management. United Kingdom: Oxford University Press.

Siena, Catherina \& Pribadi, Muhammad Adi. (2019). Interaksi Simboik Dalam Sales Promotion Menciptakan Brand Loyalty (Studi Kasus Pengguna Kartu Starbucks Di Jakarta).

Tee, Erdiansyah, dan Aulia. (2020). Pengaruh Word of Mouth dan Brand Awareness terhadap Keputusan Pembelian Xing Fu Tang di Indonesia. Prologia, Vol 4 (1).

Yin, Robert K. (2014). Studi Kasus Desain \& Metode. Jakarta: PT RajaGrafindo. 